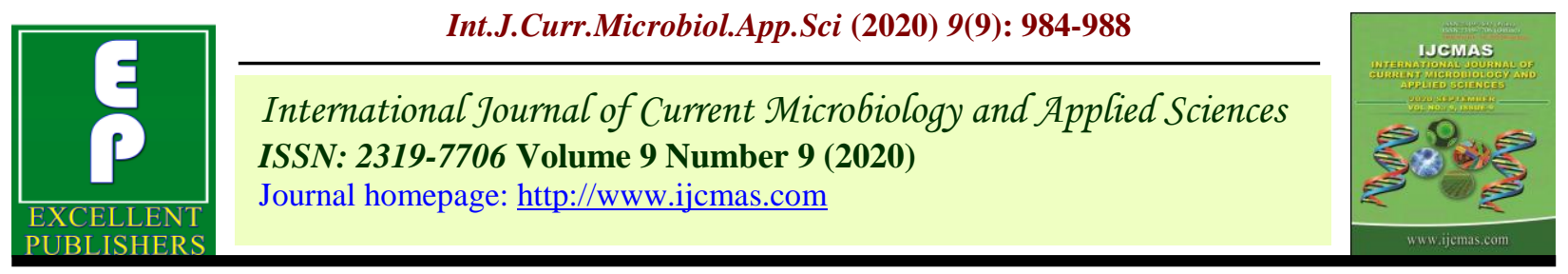

Original Research Article

https://doi.org/10.20546/ijcmas.2020.909.122

\title{
Cultural and Morphological Variability among Different Isolates of Macrophomina phaseolina causing Stem and Root Rot of Sesame
}

\author{
Lalita Lakhran* and R. R. Ahir \\ Department of Plant Pathology, Sri Karan Narendra Agriculture University, \\ Jobner, Jaipur (Rajasthan) 303329, India \\ *Corresponding author
}

\section{A B S T R A C T}

Ke y w o r d s
Colony,
Morphological,
Sclerotia, Stem and
root rot

\section{Introduction}

Sesame (Sesamum indicum L.) is valuable and edible seed crop belongs to family Padaliaceae. Seed is highly rich in quality proteins and essential amino acids, especially methionine which is considered as rejuvenative and anti-aging for human body. Sesame oil is useful for soap making, skin care industries, health food industries and cosmatic purpose. Sesame oil is cholestrol free and stable doesn't form rancid. It seed used as sweets making and medicinal forms. It is generally called as "Til" and popularly known as "Queen of oilseeds". Sesame ranked first among oil seed crops in oil content (50-
52\%) with significant dietary energy (6335 kcal per kg) (Kumar and Goel, 1994). Sesame mainly grown under tropical and subtropical regions of India with an annual acreage of around 19.17 lakh ha and production of about 8.66 lakh tonnes with $413 \mathrm{~kg}$ / ha productivity (Anonymous, 2017). Sesame area and productivity decline due to poor crop management and severe biotic and abiotic stresses. During disease development Macrophomina phaseolina is infect the sesame plant in any stage of growth when temperature varies from $28^{\circ} \mathrm{C}$ to $32^{\circ} \mathrm{C}$ and germination of microsclerotia showed maximal growth at $30-33^{0} \mathrm{C}$ (Viana and De Souza, 2002). The symptoms were appears 
both surface and ground level. The stem rupturing upward and becomes blackish in colour. The roots will become brittle and black colour dots appear on stem. In several form of diseased plants showed that the black capsules has immature and shriveled seed. The assortment of host species and their wide availability have revealed that $M$. phaseolina is non host specific and hetero-geneous.

Germinating microsclerotia produced germ tube and penetrate through natural openings in vascular tissues and colonized their (Bressano et al., 2010, Wyllie and scott, 1988). After penetration of pathogen during initial stage no visible symptoms may occurs in aerial part of the plant and remain latent (Pratt, 2006). During growing seasons plants shows wilted and necrotic symptoms due to blockage of vascular bundles with microsclerotia and secretion of toxic substances (Gupta et al., 2012). The fungus can infect 100 families with 500 plant species in overall world (Mihail and Taylor 1995 and Srivastava et al., 2001). The pathogen survives in adverse conditions by formation of sclerotia and dormant mycelium on crop residues and soil. Isolates collected from different areas of Rajasthan, characterized on their colony parameters viz., colony colour, colony appearances, sclerotial size and shape and their spore formation. Macrophomina phaseolina is seed and soil borne pathogen, so its management cultural and morphological chracterstices was observed and classified into different categories.

\section{Materials and Methods}

\section{Variability of the pathogen}

Single hyphal tip cultures were raised from isolates of ten collections of Macrophomina phaseolina on potato dextrose agar (PDA) slants. A total of ten isolates of Macrophomina phaseolina were established from the surveyed districts of Rajasthan and used in present study. Isolates were transferred separately on PDA in Petri dishes to study in detail for their discernible characters on the basis of cultural and morphological characters such as the colony diameter, colour and growth patterns. For pathogenic variability, the susceptible variety (VRI- 1) was inoculated with different isolates separately.

The isolates were coded as:

\begin{tabular}{|l|l|l|l|c|}
\hline S.No. & District & Tehsil & Village & Isolate No. \\
\hline $\mathbf{1 .}$ & Pali & Sumerpur & Angor & Mpp1 \\
\hline $\mathbf{2 .}$ & Pali & Desuri & Sadari & Mpp2 \\
\hline $\mathbf{3 .}$ & Jodhpur & Bilada & Bilada & Mpjd1 \\
\hline $\mathbf{4 .}$ & Jodhpur & Mandor & Mandor & Mpjd2 \\
\hline $\mathbf{5 .}$ & Nagaur & Molasar & Molasar & Mpng1 \\
\hline $\mathbf{6 .}$ & Nagaur & Degana & Degana & Mpng2 \\
\hline $\mathbf{7 .}$ & Tonk & Malpura & Bagri & Mptn1 \\
\hline $\mathbf{8 .}$ & Tonk & Deoli & Beejwar & Mptn2 \\
\hline $\mathbf{9 .}$ & Jaipur & Phulera & Basingpura & Mpjp9 \\
\hline $\mathbf{1 0 .}$ & Jaipur & Kisangarh Renwal & Kisangarh Renwal & Mpjp10 \\
\hline
\end{tabular}

\section{Cultural and morphological variability}

All the ten isolates were grown on Potato Dextrose Agar (PDA) medium and cultural characters like colony diameter, colour and growth pattern were studied. The observation on colony colour and texture were recorded at $7^{\text {th }}$ day of incubation. Required quantity of the above mentioned solid medium was prepared 
and sterilized at $1.05 \mathrm{~kg} / \mathrm{cm}^{2}$ pressure for 20 minutes. Sterilization of Petri dishes was done at $180^{\circ} \mathrm{C}$ for $2 \mathrm{~h}$ in a hot air oven. In each Petri dish, $25 \mathrm{ml}$ of medium was poured. Each treatment was replicated four times. Each Petri dish was inoculated with a mycelial bit of $5 \mathrm{~mm}$ diameter maintained on plain agar. The inoculated Petri dishes were incubated at $25 \pm 1^{\circ} \mathrm{C}$ temperature and observations on mycelial growth were recorded accordingly.

\section{Results and Discussion}

Variability of different isolates of $M$. phaseolina through Morphological and cultural characteristics

The cultural and morphological characteristics such as colour and appearance of colony, mycelial growth, branching pattern, size and shape of their sclerotia of different isolates of Macrophomina phaseolina were recorded by growing them on PDA medium. The results were presented Table 1 revealed that there were notified variation in colony growth rates of ten isolates of fungus (measured at 7 days after inoculation) were observed and the colony growth rate of these ten isolates followed the sequence of descending order as MPjd1 (90mm) > MPng1 (89.20mm) > MPjp2 $(87.50 \mathrm{~mm})>\operatorname{MPpa} 2(84.78 \mathrm{~mm})>\mathrm{MPjd} 2$ $(82.00 \mathrm{~mm})>$ MPpa1 $(79.15 \mathrm{~mm})>$ MPng2 $(78.50 \mathrm{~mm})>$ MPjp1 $(70.00 \mathrm{~mm})>$ MPtn 1 $(67.50 \mathrm{~mm})>$ MPtn2 $(64.00 \mathrm{~mm})$. Based on the colony appearance the MPpa1, MPng1, MPng2, MPjd1 and MPjp1 characterised as fast growing isolates whereas MPpa2, MPjd2, and MPjp2 as moderate growing isolates and MPtn1 and MPtn2 as slow growing isolates. The isolates also showed different type of colony colour and appearance. MPjd1 appeared as blackish in colour with excellent sclerotial formation whereas MPtn1 and MPtn2 were emerged as whitish and whitish creamy in colour, respectively without any sclerotial formation. MPng1 and MPjp1 showed round shaped sclerotia whereas MPtn1, MPtn2, MPjd2 and MPpa1 were observed oblong shaped sclerotia. The MPpa2 and MPjp2 isolates developed ovul shaped whereas MPng2 and MPjd 2 were showed irregular shaped sclerotia under fluorescence microscopy. All the ten isolates showed right angle type of branching pattern. However, they had significant variation in size of sclerotia ranged from 70.27- 106.50um. The maximum size of sclerotia was reported with MPjd1 (106.50um) followed by Mpjp1 (99.00um), MPtn2 (98.32um), MPng1 (93.00um), MPjd2 (90.25um) and Mptn1 (87.98um). The lowest size of sclerotia on culture media was observed in isolate MPpa1 (70.27um) and MPjp2 (77.50um). The cultural and morphological apperances of the pathogen on culture media viz, colony colour, appearance, mycelial growth, branching pattern, sclerotia shape and size were recorded for different isolates of $M$. phaseolina with the help of florescence microscopy. The results showed that isolates of $M$. phaseolina were different in their colony characters, colony colour and colony diameter.

The present investigations were supported by Riaz et al., (2007) in sunflower. Shekhar et al., (2012) observed a direct correlation between sclerotial production and virulence of isolates against charcoal rot on maize and collected seven isolates were characterized on their cultural and pathogenic characterstics. Kaur et al., (2013) worked on sixty one isolates of $M$. phaseolina in pigeon pea and differentiated on the basis of their morphological and cultural characters. Iqbal and Mukhtar (2014) reported sixty five isolates and analyzed that the radial growth of pathogen ranged from 32.00 to $87.17 \mathrm{~mm}$ and significant variation detected among sixty five isolates on their radial growth, sclerotial size, weight as well as pathogenicity test. 
Table.1 Cultural and morphological characteristics of different isolates of Macrophomina phaseolina

\begin{tabular}{|l|l|l|l|c|c|c|c|c|}
\hline $\begin{array}{l}\text { S. } \\
\text { N. }\end{array}$ & Isolates & \multicolumn{1}{|c|}{$\begin{array}{c}\text { Colour } \\
\text { colony }\end{array}$} & $\begin{array}{l}\text { Colony } \\
\text { appearance }\end{array}$ & $\begin{array}{c}\text { Mycelial } \\
\text { growth } \\
\text { (mm) }\end{array}$ & $\begin{array}{c}\text { Branching } \\
\text { pattern }\end{array}$ & $\begin{array}{c}\text { Sclerotial } \\
\text { size (um) }\end{array}$ & $\begin{array}{c}\text { Sclerotial } \\
\text { shape }\end{array}$ & $\begin{array}{c}\text { Sclerotial } \\
\text { Formation }\end{array}$ \\
\hline 1 & MPpa1 & $\begin{array}{l}\text { Whitish } \\
\text { grey }\end{array}$ & $\begin{array}{l}\text { Fast } \\
\text { growing }\end{array}$ & 79.15 & Right & 70.27 & oblong & ++ \\
\hline 2 & MPpa2 & $\begin{array}{l}\text { Brownish } \\
\text { grey }\end{array}$ & $\begin{array}{l}\text { Moderate to } \\
\text { less growing }\end{array}$ & 84.78 & Right & 80.50 & ovul & ++++ \\
\hline 3 & MPj1 & Blackish & $\begin{array}{l}\text { Fast } \\
\text { growing }\end{array}$ & 90.00 & Right & 106.50 & oblong & +++ \\
\hline 4 & MPj2 & $\begin{array}{l}\text { Blackish } \\
\text { brown }\end{array}$ & $\begin{array}{l}\text { Moderate } \\
\text { growing }\end{array}$ & 82.00 & Right & 90.25 & Irregular & ++++ \\
\hline 5 & MPng1 & $\begin{array}{l}\text { Creamy } \\
\text { brown }\end{array}$ & $\begin{array}{l}\text { Fast } \\
\text { growing }\end{array}$ & 89.20 & Right & 93.83 & Round & ++++ \\
\hline 6 & MPng2 & $\begin{array}{l}\text { Whitish } \\
\text { grey }\end{array}$ & $\begin{array}{l}\text { Fast } \\
\text { growing }\end{array}$ & 78.50 & Right & 81.74 & Irregular & ++++ \\
\hline 7 & MPjp1 & $\begin{array}{l}\text { Grayish } \\
\text { white }\end{array}$ & $\begin{array}{l}\text { Fast } \\
\text { growing }\end{array}$ & 70.00 & Right & 99.00 & Round & +++ \\
\hline 8 & MPjp2 & $\begin{array}{l}\text { Blackish } \\
\text { brown }\end{array}$ & $\begin{array}{l}\text { Moderate } \\
\text { growing }\end{array}$ & 87.50 & Right & 77.50 & Ovul & +++ \\
\hline 9 & MPtn1 & $\begin{array}{l}\text { Whitish } \\
\text { Slow } \\
\text { growing }\end{array}$ & 67.50 & Right & 87.98 & Oblong & +++ \\
\hline 10 & MPtn2 & $\begin{array}{l}\text { Whitish } \\
\text { creamy }\end{array}$ & $\begin{array}{l}\text { Slow } \\
\text { growing }\end{array}$ & 64.00 & Right & 98.32 & Oblong & ++++ \\
\hline
\end{tabular}

0= no sclerotial formation; 1-10 $(+)=$ Poor, 11-20 $(++)=$ Moderate, $21-30(+++)=$ Good, $>30(++++)=$ Excellent

Satpathi and Gohel (2018) and Wagan et al., (2018) also worked on same pathogen and collected different isolates, the isolates were categorized on their morphological and cultural features and observed the colony colour, radial growth, shape and size of sclerotia.

In conclusion for management of stem and root rot pathogen we need know out their variability and survivability in soil. Different isolates were isolated from samples collected from different sesame growing surveyed areas of Rajasthan and classified on their morphological and cultural characteristics and seen variability between different collected isolates. Variation among ten isolates is colony appearance, colony colour, mycelia growth, branching pattern sclerotial size, shape and their formulation were recorded. Isolate MPjd1, MPjp1, MPng1, MPng2, MPpa1 and MPpa2 showed $100 \%$ mycelial growth after seven days of inoculation on PDA plates, colony appeared less to fast growing mycelial growth with right angle branching pattern. Colony coloured varied from whitish grey to blackish in colour and formed sclerotia. Sclerotial size varies from 70.27106.50 um. Shape of sclerotia was oblong, round, ovul and irregular type.

\section{References}

Anonymous (2017) IOPEPC Kharif-2017 Survey of sesame crop. Indian oilseed and produce export promotion council (Under ministry of commerce, Govt. of India) 78-79, Bajaj Bhawan, Nariman 
point, Mumbai.

Bressano M, Giachero ML, Luna CM, Ducasse DA (2010) An in vitro method for examining infection of soyabean roots by Macrophomina phaseolina. Physiological molecular Plant Pathology 74: 201-204.

Gupta GK, Sharma SK, Ramteke R (2012) Biology, epidemiology and management of the pathogenic fungus Macrophomina phaseolina (Tassi) Goid with special reference to charcoal rot of soybean (Glycine max (L.) Merril. Journal of Phytopathology 160:167-180.

Iqbal U, Mukhtar T (2014) Morphological and Pathogenic Variability among Macrophomina phaseolina Isolates Associated with Mungbean (Vigna radiata L.) Wilczek from Pakistan. Scientific World Journal pp.19

Kaur S, Dhillon GS, Brar SK, Valled GE, Chand R, Chauhan VB (2013) Emerging Phytopathogen Macrophomina phaseolina: biology, economic importance and current diagnostic trends. Critical review in microbiology $1-16$

Kumar S, Goel PD (1994). A great ancient oilseed sesamum. Farmers and Parliament. 12: 6-7.

Mihail JD, Taylor SJ (1995) Interpreting variability among isolates of Macrophomina phaseolina in pathogenicity, pycnidium production, and chlorate utilization. Canadian Journal of Botany 73: 1596-1603.

Pratt RG (2006) A Direct observation technique for evaluting sclerotium germination by Macrophomina phaseolina and effects of bio- control materials on the survival of sclerotia in soil. Mycopathologia. 162: 121-131.
Riaz AS, Khan H, Iqbal SM, Shoaib M (2007) Pathogenic variability among Macrophomina phaseolina (Tassi) Goid, isolates and identification of sources of resistance in mash against charcoal rot Pakistan Journal of Phytopathology 19(1): 44-46.

Satpathi AK, Gohel NM (2018a) Cultural and morphological variability among the isolates of Macrophomina phaseolina (Tassi) Goid. Causing stem and root rot of sesame (Sesamum indicum L.). International Journal of Chemical Studies 6(6): 2890-2893.

Shekhar M, Sharma RC, Singh L, Datta R (2012) Morphological and pathogenic variability of Macrophomina phaseolina (Tassi) Goid. Incitant of Charcoal rot maize in India. Indian Phytopathology 59(3): 294-298.

Srivastava AK, Singh T, Jana TK, Arora DK (2001) Microbial colonization of Macrophomina phaseolina and suppression of charcoal rot of chickpea. (In: Sinha, A. (eds.), Microbes and Plants (pp. 269-319), Vedams eBooks (P) Ltd. New Delhi, 2001.

Viana FMP, De Souza NL (2002) Effect of temperature water tension interaction on germination of Macrophomina phaseolina microsclerotia. Fitopatol. Bras. 27: 268-272

Wagan HK, Khaskheli MI, Hajano J, Lanjar AG (2018) Isolation and characterization of Macrophomina phaseolina isolates prevailing in Sindh, Pakistan. Pure and Applied Biology. 11(7): 9342-9358.

Wullie TD, Scott DH (1988). Charcol rot of soyabeans- current status. In soyabean diseases of north central region. APS Press Indianapolis, IN, pp. 106-113.

\section{How to cite this article:}

Lalita Lakhran and Ahir, R. R. 2020. Cultural and Morphological Variability among Different Isolates of Macrophomina phaseolina causing Stem and Root Rot of Sesame. Int.J.Curr.Microbiol.App.Sci. 9(09): 984-988. doi: https://doi.org/10.20546/ijcmas.2020.909.122 